\title{
LOSS OF EXTRACTION CAPACITY OF MEHLICH-1 AND MONOCALCIUM PHOSPHATE AS A VARIABLE OF REMAINING P AND ITS RELATIONSHIP TO CRITICAL LEVELS OF SOIL PHOSPHORUS AND SULFUR
}

\author{
Sarah Vieira Novais ${ }^{(1)}$, Edson Marcio Mattiello( ${ }^{(2)}$, Leonardus Vergutz ${ }^{(2)}$, Leônidas Carrijo \\ Azevedo Melo ${ }^{(2)}$, Írio Fernando de Freitas ${ }^{(2)}$ and Roberto Ferreira Novais ${ }^{(3)^{*}}$ \\ (1) Universidade de São Paulo, Escola Superior de Agricultura Luiz de Queiroz, Programa de Pós-graduação em Ciência do Solo, \\ Piracicaba, São Paulo, Brasil. \\ (2) Universidade Federal de Viçosa, Departamento do Solo, Viçosa, Minas Gerais, Brasil. \\ (3) Universidade Federal de Viçosa, Instituto de Ciências Agrárias, Campus de Rio Paranaíba, Rio Paranaíba, Minas Gerais, Brasil. \\ * Corresponding author. \\ E-mail: rfnovais@ufv.br
}

\begin{abstract}
The Mehlich-1 (M-1) extractant and Monocalcium Phosphate in acetic acid (MCPa) have mechanisms for extraction of available $P$ and $S$ in acidity and in ligand exchange, whether of the sulfate of the extractant by the phosphate of the soil, or of the phosphate of the extractant by the sulfate of the soil. In clayey soils, with greater $P$ adsorption capacity, or lower remaining P (Rem-P) value, which corresponds to soils with greater Phosphate Buffer Capacity (PBC), more buffered for acidity, the initially low $\mathrm{pH}$ of the extractants increases over their time of contact with the soil in the direction of the $\mathrm{pH}$ of the soil; and the sulfate of the M-1 or the phosphate of the MCPa is adsorbed by adsorption sites occupied by these anions or not. This situation makes the extractant lose its extraction capacity, a phenomenon known as loss of extraction capacity or consumption of the extractant, the object of this study. Twenty soil samples were chosen so as to cover the range of Rem-P (0 to $\left.60 \mathrm{mg} \mathrm{L}^{-1}\right)$. Rem-P was used as a measure of the PBC. The $P$ and $S$ contents available from the soil samples through M-1 and MCPa, and the contents of other nutrients and of organic matter were determined. For determination of loss of extraction capacity, after the rest period, the $\mathrm{pH}$ and the $\mathrm{P}$ and $\mathrm{S}$ contents were measured in both the extracts-soils. Although significant, the loss of extraction capacity of the acidity of the M-1 and MCPa extractants with reduction in the Rem-P value
\end{abstract}


did not have a very expressive effect. A "linear plateau" model was observed for the M-1 for discontinuous loss of extraction capacity of the $P$ content in accordance with reduction in the concentration of the Rem-P or increase in the PBC, suggesting that a discontinuous model should also be adopted for interpretation of available $P$ of soils with different Rem-P values. In contrast, a continuous linear response was observed between the $P$ variables in the extract-soil and Rem-P for the MCPa extractor, which shows increasing loss of extraction capacity of this extractor with an increase in the PBC of the soil, indicating the validity of the linear relationship between the available $S$ of the soil and the PBC, estimated by Rem-P, as currently adopted.

Keywords: $\mathrm{P}$ adsorption, $\mathrm{S}$ adsorption, available nutrient, phosphate buffer capacity, extractant.

\title{
RESUMO: DESGASTE DOS EXTRATORES MEHLICH-1 E FOSFATO MONOCÁLCICO COMO VARIÁVEL DO P-REMANESCENTE E SUA RELAÇÃO COMOS NÍVEIS CRÍTICOS DE FÓSFORO E DE ENXOFRE NOS SOLOS
}

\begin{abstract}
O extrator Mehlich-1 (M-1), assim como o Fosfato Monocálcico em ácido acético (FMCa), tem na acidez e na troca de ligantes - seja do sulfato do extrator pelo fosfato do solo ou do fosfato do extrator pelo sulfato do solo - os mecanismos de extração do $P$ e do $S$ disponíveis. Em solos argilosos, com maior poder de adsorção de P, ou menor valor de P-remanescente (P-rem), o que corresponde a solos com maior Poder-Tampão de Fosfato (PTF), mais tamponados para a acidez, o pH inicialmente baixo dos extratores é, durante o seu contato com o solo, aumentado em direção àquele do solo, e o sulfato do M-1 ou o fosfato do FMCa é adsorvido por sítios de adsorção ocupados ou não por esses ânions. Tal fato faz com que o extrator perca seu poder de extração, fenômeno conhecido como desgaste de extrator, objetivo de estudo deste trabalho. Escolheram-se 20 amostras de solos, de modo a cobrir a faixa do P-rem (0 a $60 \mathrm{mg} \mathrm{L-1).} \mathrm{Como}$ medida do PTF, foi utilizado o P-rem. Os teores de $P$ e de $S$ disponíveis das amostras dos solos pelo $M-1$ e FMCa, de demais nutrientes e de matéria orgânica (MO) foram determinados. Para a determinação do desgaste dos extratores, após o período de repouso, foram medidos o $\mathrm{pH}$ e os teores de $\mathrm{P}$ e de $\mathrm{S}$ em ambos os extratos-solos. Houve efeito pouco expressivo, embora significativo, do desgaste da acidez dos extratores M-1 e FMCa com a diminuição do valor de P-rem. Observou-se para o M-1 um modelo linear plateau para desgaste descontínuo do teor do $P$, com a diminuição da concentração do P-rem ou aumento do PTF, sugerindo que se deve adotar um modelo também descontínuo para a interpretação do P-disponível de solos com diferentes valores de P-rem. Entretanto, observou-se resposta linear-contínua entre as variáveis $P$ no extrato-solo e P-rem para o extrator FMCa, o que evidenciou desgaste crescente desse extrator com o aumento do PTF do solo, indicando a validade da relação linear entre o $S$ disponível do solo e o PTF, estimado pelo P-rem, como atualmente adotada.
\end{abstract}

Palavras-chave: adsorção de $P$, adsorção de $S$, nutriente disponível, poder-tampão de fosfato, extrator.

\section{INTRODUCTION}

The Mehlich-1 extractant (M-1) has the mechanisms of extraction of available $\mathrm{P}$ in its acidity ( $\mathrm{pH} 1.2$ ) and in the ligand exchange of its sulfate by soil phosphate. In clayey soils and in those with greater organic matter $(\mathrm{OM})$ contents, more buffered for acidity, the initially low $\mathrm{pH}$ of the $\mathrm{M}-1$ increases in direction of that of the soil when shaken together with the soil sample. The sulfate is likewise adsorbed to the adsorption sites occupied by this anion or not. This makes the extractant lose its extraction capacity, an occurrence known as loss of extraction capacity or consumption of the extractant (Novais and Smyth, 1999; Freitas et al., 2013).
In a similar manner, the Monocalcium Phosphate in acetic acid (MCPa), $\mathrm{pH} 2.2$, extracts the available $\mathrm{S}$ from the soil by the exchange of the sulfate adsorbed with the phosphate of this extractant. Thus, with the increase in the capacity of $\mathrm{P}$ adsorption of the soil in greater clay content or lower remaining $\mathrm{P}$ (Rem-P) value, which corresponds to soils with greater PBC, the phosphate of the extractant is also consumed by adsorption sites, including those not yet occupied by $\mathrm{S}$, reducing the extraction capacity of this nutrient as a consequence of the consumption of the extractant.

The practical importance of this consumption is understood in evaluation of results of routine analyses of soil fertility that use Rem-P (Bedin et al., 2003; Bonfim et al., 2004; Corrêa et al., 2008; Fernández R. et al., 2008) or the clay content 
(Donagemma et al., 2008) as a measure of PBC, essential for interpretation of the $\mathrm{P}$ and $\mathrm{S}$ contents obtained. However, in general, the decrease in the Critical Level (CL) of these nutrients with the decrease in Rem-P has not been appropriately understood or described in the literature.

Some disadvantages, such as laboratory difficulties in textural analyses, the frequently incomplete dispersion of clay in tropical soils in general (Donagemma et al., 2003; Vitorino et al., 2003), and the lack of determination of the quality of clay in routine laboratory testing impede and limit the use of clay content as a measure of PBC, making analysis of Rem-P, which is easily and quickly performed, a suitable and more exact measurement of the PBC for this objective (Alvarez V et al., 2000; Corrêa et al., 2011).

Like the essential nature of a measure of buffer capacity of soil acidity for determination of the need for liming, the behavior of $\mathrm{P}$ in the soil is dependent on a measurement of the PBC of this soil for interpretation of results of its availability and the consequent recommendation of the optimum application rate of a phosphate fertilizer for growing a plant.

In a functional or practical approach of interpretation of results of available $\mathrm{P}$ and $\mathrm{S}$ in routine analyses of soil fertility, in regard to applicability and lower cost, with the necessary exactness of a measurement of PBC, the Rem-P method was developed. For this purpose, Bache and Williams (1971) developed a first approximation ("phosphate adsorption index" or "single concentration adsorption") of what is now called Rem-P. These authors established the rate of $\mathrm{P}$ added to the soil in order to have a defined concentration of $\mathrm{P}$ in the equilibrium solution. This "index", therefore, has a positive correlation with PBC, whereas Rem-P, which measures the "remaining amount" in the equilibrium solution of a constant concentration of $\mathrm{P}$ added to the soil, has a negative correlation with $\mathrm{PBC}$.

Novais (1977) used only one of the concentrations of $\mathrm{P}\left(30 \mathrm{mg} \mathrm{L}^{-1}\right)$ among those used for obtaining Langmuir and Freundlich adsorption isotherms in equilibrium after $6 \mathrm{~h}$ of shaking with soil samples, which was called Rem-P concentration ("Remaining $\mathrm{P}$ in solution"), as a measure of PBC. Negative and highly significant correlations were found between this characteristic and measurements such as the Maximum P Adsorption Capacity (MPAC) of Langmuir, as well as other soil variables closely related to the PBC. After that, Delazari (1979) individually compared the equilibrium concentrations of $5,10,20,30,40,50$, and $60 \mathrm{mg} \mathrm{L}^{-1}$ with $1 \mathrm{~h}$ of shaking and these same concentrations with the addition of 80 and $100 \mathrm{mg} \mathrm{L}^{-1}$ with $24 \mathrm{~h}$ of shaking used in fitting the Langmuir adsorption isotherm. The correlations with MPAC had an increase in their absolute values, with up to $30 \mathrm{mg} \mathrm{L}^{-1}$ with1 h of shaking, and with up to $60 \mathrm{mg} \mathrm{L}^{-1}$ with $24 \mathrm{~h}$ of shaking.

Several studies have shown the suitability (through exactness and simplicity) of the use of the Rem-P 60 (60 $\mathrm{mg} \mathrm{L}^{-1}$ of P) (Alvarez V et al., 2000; Corrêa et al., 2008), both for interpretations of the results of soil available P (Ribeiro et al., 1999; Bedin et al., 2003; Côrrea et al., 2011) and S (Ribeiro et al., 1999; Souza, 1999; Rampim et al., 2013).

The Rem-P has a probable direct relationship with OM content, since greater OM contents may result in lower $\mathrm{P}$ adsorption and greater CLs for this nutrient, given the lower loss of extraction capacity (M-1 sulfate exhaustion) in this condition (Novais and Smyth, 1999; Rheinheimer and Anghinoni, 2001), as opposed to what occurs under the condition of soils with greater clay contents - with greater loss of extraction capacity (Bahia Filho et al., 1983; Neves et al., 1987). In contrast, Eberhardt et al. (2008) found a positive correlation between OM content and clay content in Latossolo (Oxisol) samples from the Cerrado (Brazilian tropical savanna).

In a hypothetical example in which, with the increase in years of cropping, there are greater contents of $\mathrm{P}$ and $\mathrm{S}$ available in the soil, tending to saturate its adsorption sites with these nutrients, the Rem-P should increase (PBC reduced), while the clay content should remain constant (PBC stable). This situation exemplifies the unsuitability of the clay content as a PBC measurement and the suitability of the Rem-P for interpretation of its contents of available $\mathrm{P}$ and $\mathrm{S}$.

The change in soil management (from conventional tillage to no-tillage, for example), which may lead to the production of more residues as a consequence of possible greater yields, makes the OM content in the soil increase and, thus, the Rem-P also increases (Andrade et al., 2003; Silva and Mendonça, 2007; Fontana et al., 2008). That suggests that over time (greater OM contents), the interpretation tables of results of soil analyses and fertilizer recommendation should change in the direction of loss of dependence on the CL to the PBC (models "b" and "c" of Figure 1). The same may be noted in regard to the increase in the available $\mathrm{P}$ content in the soil over years of cropping or when soils are considered with greater contents of $2: 1$ clays (CL not very sensitive to or independent of the clay content). Model "c" of figure 1 then becomes more representative of the phenomenon. Thus, over the years of sustainable cropping in Cerrado soils, for example, the interpretation tables of soil analysis for available $\mathrm{P}$ and $\mathrm{S}$ should become independent of the PBC, unlike what currently occurs with Rem-P or even clay content. 
(a)

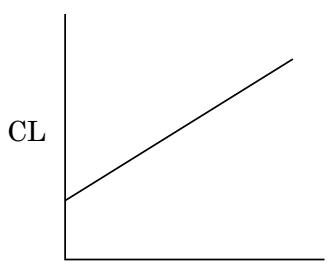

(b)

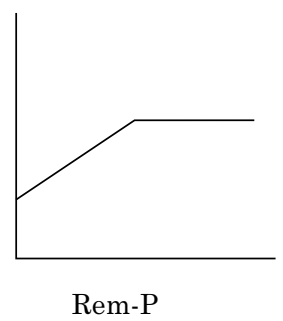

(c)

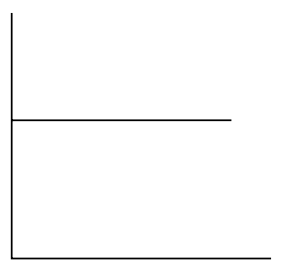

Figure 1. Relationship between the critical level (CL) of available $P$ by the Mehlich-1 extractant and remaining $P($ Rem-P) in soils of great loss of extraction capacity (a), of intermediate loss of extraction capacity (b), and without loss of extraction capacity (c). Source: Novais and Smyth (1999).

The "b" curve of figure 1 was found by Novais and Smyth (1999) upon placing the results of the CL of P by M-1 of nine soil samples as the dependent variable of Rem-P, as a measurement of PBC, obtained by Muniz et al. (1987) under conditions nearer to the beginning of the opening of the Cerrado areas. This observation indicates that the "a" curve of this figure would just not occur at that time of lower $\mathrm{P}$ residues and probable lower OM contents in the soils.

The aim of this study was to evaluate the chemical loss of extraction capacity of the extractant M-1 and $\mathrm{MCPa}$ from soil-available $\mathrm{P}$ and $\mathrm{S}$, respectively, as variables of the increase in buffering capacity of acidity and of the PBC of soils, and suggest the pairing of these losses of extraction capacity with the variation of the CL of these two nutrients in soils with different values of Rem-P.

\section{MATERIAL AND METHODS}

This study was carried out in the Standard Soil Fertility Laboratory of the Soil Department of the Universidade Federal de Viçosa, Viçosa, Minas Gerais, Brazil. For that purpose, 20 soil samples were taken, air dried, passed through a sieve with a $2 \mathrm{~mm}$ screen, and analyzed, chosen so as to cover the Rem-P range - theoretical values from 0 to $60 \mathrm{mg} \mathrm{L}^{-1}$, without taking into consideration other chemical or physical properties of the soils, such as origin, texture, color, etc.

For soil analyses (Table 1), the protocols cited in Embrapa (2009) were adopted. Available $\mathrm{P}$ and $\mathrm{K}$ were extracted by $\mathrm{M}-1$ $\left(0.0125 \mathrm{~mol} \mathrm{~L}^{-1} \mathrm{H}_{2} \mathrm{SO}_{4}+0.05 \mathrm{~mol} \mathrm{~L}^{-1} \mathrm{HCl}\right)$ in a soil-extractant ratio of $1: 10$, shaking for $5 \mathrm{~min}$ and rest for $16 \mathrm{~h}$. Available $\mathrm{S}$ was extracted by a monocalcium phosphate solution, with $500 \mathrm{mg} \mathrm{L}^{-1}$ of $\mathrm{P}$ in $2 \mathrm{~mol} \mathrm{~L}^{-1}$ acetic acid (MCPa) in the soil-extractant ratio of 1:2.5, shaking for 5 min and rest for $16 \mathrm{~h}$. For $\mathrm{Ca}^{2+}, \mathrm{Mg}^{2+}$, and $\mathrm{Al}^{3+}$, a $1 \mathrm{~mol} \mathrm{~L}^{-1} \mathrm{KCl}$ solution was used, and potential acidity $(\mathrm{H}+\mathrm{Al})$ was determined in a $0.5 \mathrm{~mol} \mathrm{~L}^{-1}$ calcium acetate solution, $\mathrm{pH} 7.0$. The

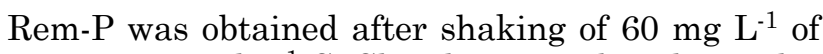
$\mathrm{P}$ in a $0.01 \mathrm{~mol} \mathrm{~L}^{-1} \mathrm{CaCl}_{2}$ solution with soil samples in the soil-solution ratio of $1: 10$ for $1 \mathrm{~h}$. The $\mathrm{pH}$ in water was obtained in a soil-water ratio of 1:2.5. The OM content was determined by the Walkley-Black method (Embrapa, 2009).

Phosphorus was determined by colorimetry of the phosphomolybdic complex with reduction with ascorbic acid, $\mathrm{K}$ was determined by flame photometry, $\mathrm{Ca}$ and $\mathrm{Mg}$ were determined by atomic absorption, $\mathrm{Al}^{3+}$ and $\mathrm{H}+\mathrm{Al}$ were determined by titration techniques, and $\mathrm{S}$ was determined by sulfate turbidimetry (Alvarez V et al., 2001).

For determination of the loss of extraction capacity after the resting period of each extractant (16h), the $\mathrm{pH}$ and the $\mathrm{S}$ and $\mathrm{P}$ contents were measured for both extractants (extract-soil), M-1 and MCPa, respectively.

The values of $\mathrm{pH}$ were fitted as dependent variables of the Rem-P of the soils to quantify the decrease (loss of extraction capacity) of the original acidity of each extractant. The same was done for the concentrations of the $\mathrm{S}$ in the extract for M-1 and of $\mathrm{P}$ for $\mathrm{MCPa}$ as variables of the Rem-P, which were plotted and fitted statistically so as to quantify the loss of extraction capacity of the extractants as a variable of the Rem-P values of the soils. These results were also used to verify the probable dependence of that observed in regard to the loss of extraction capacity of the two extractants with the model of decline of the CLs of soil-available P and S, with the increase in the $\mathrm{PBC}$ or reduction in the Rem-P.

\section{RESULTS AND DISCUSSION}

\section{Loss of extraction capacity of the acidity of the extractants}

Soil sample 16, with high $\mathrm{pH}$ (6.29), $440 \mathrm{~g} \mathrm{~kg}^{-1}$ of clay, and OM content of $56.3 \mathrm{~g} \mathrm{~kg}^{-1}$ (Table 1) is characterized by high buffering capacity of acidity, just as soil sample 20 (Figure 2), with initial $\mathrm{pH}$ of 
Table 1. Results of the routine chemical analyses and the clay content of the soils

\begin{tabular}{|c|c|c|c|c|c|c|c|c|c|c|c|c|c|c|c|c|}
\hline Soil & $\mathrm{pH}\left(\mathrm{H}_{2} \mathrm{O}\right)$ & Rem-P & $\mathbf{P}$ & $\mathrm{S}$ & $\mathbf{K}$ & $\mathrm{Ca}^{2+}$ & $\mathrm{Mg}^{2+}$ & $\mathrm{Al}^{3+}$ & $\mathrm{H}+\mathrm{Al}$ & SB & $\mathbf{t}$ & $\mathbf{T}$ & $\mathrm{V}$ & $\mathbf{m}$ & OM & Clay \\
\hline & & $\mathrm{mg} \mathrm{L}^{-1}$ & & $\mathrm{~g} \mathrm{dm}^{-3}$ & & \multicolumn{7}{|c|}{$\mathrm{cmol}_{\mathrm{c}} \mathrm{dm}^{-3}$} & \multicolumn{2}{|c|}{$\%$} & \multicolumn{2}{|c|}{$\mathrm{g} \mathrm{kg}^{-1}$} \\
\hline 1 & 5.89 & 3.50 & 0.70 & 6.07 & 2.00 & 0.05 & 0.00 & 0.00 & 2.70 & 0.06 & 0.06 & 2.76 & 2.20 & 0.00 & 6.30 & 280 \\
\hline 2 & 5.50 & 5.00 & 0.40 & 11.26 & 4.00 & & 0.00 & 0.00 & 7.70 & 0.10 & 0.10 & 7.80 & 1.30 & 0.00 & 33.90 & 530 \\
\hline 3 & 5.56 & 5.10 & 0.90 & 12.46 & 7.00 & 0.07 & 0.01 & 0.00 & 6.90 & 0.10 & 0.10 & 7.00 & 1.40 & 0.00 & 25.10 & 280 \\
\hline 4 & 5.29 & 8.00 & 0.60 & 18.80 & 14.00 & 0.08 & 0.03 & 0.00 & 7.70 & 0.15 & 0.15 & 7.85 & 1.90 & 0.00 & 23.90 & 450 \\
\hline 5 & 4.74 & 11.00 & 1.10 & 30.61 & 32.00 & 0.09 & 0.06 & 0.39 & 9.30 & 0.24 & 0.63 & 9.54 & 2.50 & 61.90 & 28.90 & 260 \\
\hline 6 & 5.12 & 14.30 & 0.50 & 23.62 & 13.00 & 0.13 & 0.02 & 2.44 & 3.90 & 0.19 & 2.63 & 4.09 & 4.60 & 92.80 & 7.50 & 260 \\
\hline 7 & 4.90 & 17.30 & 0.80 & 22.41 & 11.00 & 0.47 & 0.16 & 0.88 & 7.40 & 0.66 & 1.54 & 8.06 & 8.20 & 57.10 & 32.60 & 600 \\
\hline 8 & 4.43 & 19.00 & 1.60 & 29.96 & 17.00 & 0.20 & 0.06 & 1.66 & 5.80 & 0.31 & 1.97 & 6.11 & 5.10 & 84.30 & 2.30 & 740 \\
\hline 9 & & 22.50 & 1.60 & 25.69 & 33.00 & & 0.11 & 1.56 & & 0.39 & 1.95 & 9.09 & 4.30 & 80.00 & & 600 \\
\hline 10 & & 24.00 & 1.50 & 25.80 & 53.00 & 1.65 & 0.45 & 0.20 & 7.60 & 2.24 & 2.44 & 9.84 & 22.80 & 8.20 & 3.84 & 610 \\
\hline 11 & & 25.70 & 0.90 & 19.24 & 12.00 & 0.67 & 0.16 & 0.49 & 6.30 & 0.87 & 1.36 & 7.17 & 12.10 & 36.00 & 26.40 & 480 \\
\hline 12 & 3.89 & 27.30 & 23.50 & 31.16 & 30.00 & 0.19 & 0.10 & 1.27 & 5.60 & 0.37 & 1.64 & 5.97 & 6.20 & 77.40 & 24.90 & 490 \\
\hline 13 & 4.08 & 31.60 & 2.00 & 22.19 & 39.00 & 0.59 & 0.33 & 0.78 & 5.20 & 1.02 & 1.80 & 6.22 & 16.40 & 43.30 & 36.40 & 500 \\
\hline 14 & & 33.40 & 0.70 & 26.46 & 6.00 & 0.09 & 0.10 & 0.78 & 3.90 & 0.21 & 0.99 & 4.11 & 5.10 & 78.80 & 11.30 & 150 \\
\hline 15 & 4.87 & 36.30 & 1.20 & 16.51 & 55.00 & 0.26 & 0.27 & 1.76 & 8.70 & 0.68 & 2.44 & 9.38 & 7.20 & 72.10 & 41.80 & 560 \\
\hline 16 & 6.29 & 38.20 & 3.80 & 10.82 & 91.00 & 4.08 & 0.95 & 0.00 & 6.00 & 5.27 & 5.27 & 11.27 & 46.80 & 0.00 & 5.63 & 440 \\
\hline 17 & & 43.30 & 1.90 & 17.38 & 66.00 & 1.26 & 0.61 & 0.59 & 5.30 & 2.04 & 2.63 & 7.34 & 27.80 & 22.40 & 16.30 & 150 \\
\hline 18 & 5.63 & 48.30 & 4.50 & 20.01 & 16.00 & 0.71 & 0.14 & 0.00 & 2.40 & 0.90 & 0.90 & 3.30 & 27.30 & 0.00 & 0.13 & 100 \\
\hline 19 & 5.05 & 53.00 & 9.10 & 15.74 & 165.00 & 2.09 & 1.50 & 0.49 & 6.90 & 4.01 & 4.50 & 10.91 & 36.80 & 10.90 & 64.60 & 640 \\
\hline 20 & 7.18 & 56.10 & 156.10 & 5.03 & 765.00 & 4.02 & 2.27 & 0.10 & 1.40 & 8.26 & 8.36 & 9.66 & 85.50 & 1.20 & 52.00 & 390 \\
\hline
\end{tabular}

pH in water, in a soil-water ratio of 1:2.5; Rem-P: Remaining phosphorus, obtained after shaking of $30 \mathrm{mg} \mathrm{L}^{-1}$ of $\mathrm{P} \mathrm{in} 0.01 \mathrm{~mol} \mathrm{~L}^{-1} \mathrm{CaCl}_{2}$ for $1 \mathrm{~h}$ in a soil-solution ratio of 1:10; $\mathrm{P}$ and $\mathrm{K}$ : extractor M-1 $\left(0.0125 \mathrm{~mol} \mathrm{~L}^{-1} \mathrm{H}_{2} \mathrm{SO}_{4}+0.05 \mathrm{~mol} \mathrm{~L}^{-1} \mathrm{HCl}\right)$; available S: extracted by $500 \mathrm{mg} \mathrm{L}{ }^{-1}$ of $\mathrm{P}$ in $2 \mathrm{~mol} \mathrm{~L}{ }^{-1}$ acetic acid solution; $\mathrm{Ca}^{2+}, \mathrm{Mg}^{2+}, \mathrm{Al}^{3+}$ : extractor $1 \mathrm{~mol} \mathrm{~L}^{-1} \mathrm{KCl}$; $\mathrm{H}+\mathrm{Al}$ : determined in a $0.5 \mathrm{~mol} \mathrm{~L}{ }^{-1}$ calcium acetate solution, $\mathrm{pH}$ 7.0; SB: sum of exchangeable bases; t: effective cation exchange capacity; T: cation exchange capacity at pH 7.0; V: base saturation; m: aluminum saturation; OM: organic matter, determined by the Walkley-Black method.

7.18, OM contents of $52.0 \mathrm{~g} \mathrm{~kg}^{-1}$, and clay contents of $90 \mathrm{~g} \mathrm{~kg}^{-1}$, which caused them greater loss of extraction capacity of acidity of the extract-soil for M-1. A similar situation occurs with soil sample 19 which, although with a lower initial $\mathrm{pH}$ of 5.05, has high OM content $\left(64.6 \mathrm{~g} \mathrm{~kg}^{-1}\right)$, and clay content $\left(640 \mathrm{~g} \mathrm{~kg}^{-1}\right)$. Thus, in these conditions of greater buffering of the soil acidity, and in a particular way for the soils with greater initial $\mathrm{pH}$, the loss of extraction capacity of the acidity of the extractant becomes more expressive (Novais and Smyth, 1999; Nolla and Anghinoni, 2006; Viégas et al., 2010). It is noteworthy that these three soils have greater contents of OM and of Rem-P, which suggests a probable negative correlation between OM content and the MPAC or PBC of these soils, as also found by Singh and Gilkes (1991) in samples of 97 highly weathered soils of Australia.

Thus, reduction in $\mathrm{P}$ adsorption is expected with the increase in the OM content of soils, as through the addition of organic residues with similar clay contents (Yusran, 2010). A similar situation to that observed for the M-1 extractant in soil samples 16 , 19 , and 20 (Table 1) occurs for the MCPa extractant in regard to loss of extraction capacity of the acidity, inconsistent with that observed for the other soils.
The $\mathrm{pH}$ of the extract-soil estimated for the condition of minimum loss of extraction capacity of the $\mathrm{M}-1$ for Rem-P $=39.9 \mathrm{mg} \mathrm{L}{ }^{-1}$ is 1.24 (Figure 2). For the MCPa extractant, these values are $42.3 \mathrm{mg} \mathrm{L}^{-1}$ and $\mathrm{pH}$ of 2.32 (Figure 3 ). These $\mathrm{pH}$ values are similar to those originally found in the extractants, i.e. M-1 of 1.2 and $\mathrm{MCPa}$ of 2.2. In contrast, under the condition of estimated maximum loss of extraction capacity (Rem-P $=0 \mathrm{mg} \mathrm{L}^{-1}$ or maximum $\mathrm{PBC}$ ), the values of $\mathrm{pH}$ of the extract-soil for M-1 is 1.49, and for MCPa, it is 2.6. Therefore, it may be seen that, in both extractants, the maximum amplitude of variation of the $\mathrm{pH}$ of the extract-soil is small and probably not responsible for the expected decreases of the CLs of $\mathrm{P}$ in the soil through M-1 with the increase in the PBC of the soil (reduction in Rem-P) (Ribeiro et al., 1999).

This type of information has practical importance for soils with high contents of the $\mathrm{P}$ fraction bonded to $\mathrm{Ca}(\mathrm{P}-\mathrm{Ca})$, when one might suppose that the M-1 would be less effective in extraction of P-Ca (Silva and Raij, 1999), given the condition more favorable to the loss of extraction capacity of the acidity of the extractant in this condition of soils with greater clay contents. 


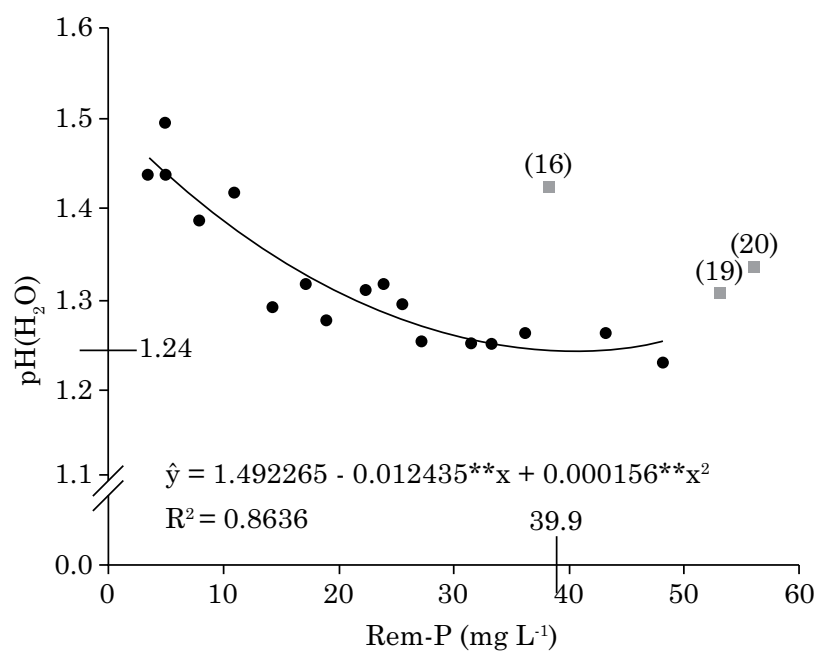

Figure 2. Values of $\mathrm{pH}\left(\mathrm{H}_{2} \mathrm{O}\right)$ of the extract-soil of Mehlich-1, as a variable of remaining $P$ values (Rem-P) of the soils. The three points identified for the soils $(\rightarrow)$ were excluded from the fit. **: significant at $1 \%$ by the test. (|) Values of $x$ and $y$ that denote the minimum point.

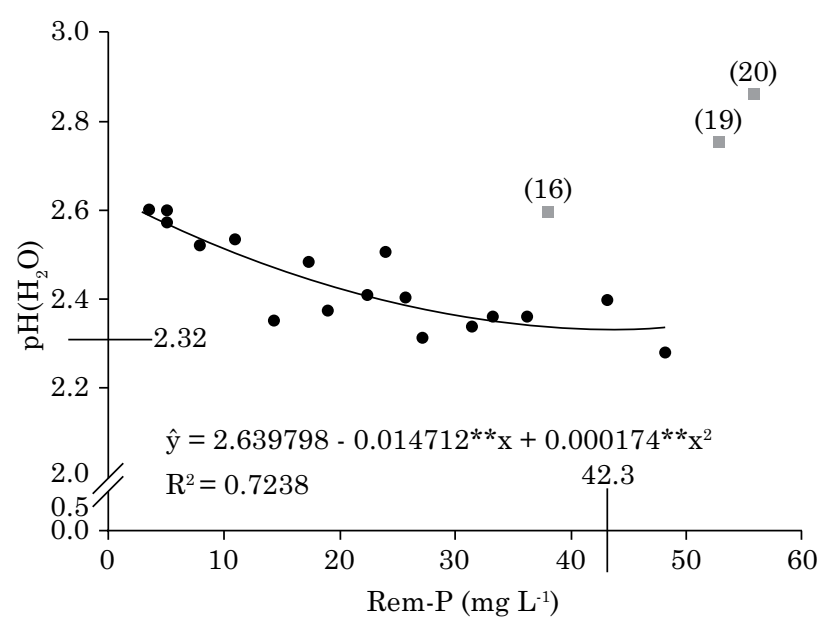

Figure 3. Values of $\mathrm{pH}\left(\mathrm{H}_{2} \mathrm{O}\right)$ of the extract-soil of Monocalcium Phosphate in acetic acid as a variable of remaining $P$ values (Rem-P) of the soils. The three points identified for the soils ( $)$ were excluded from the fit. **: significant at $1 \%$ by the $t$ test. (|) Values of $x$ and $y$ that denote the minimum point.

\section{Loss of extraction capacity of anions of extractants}

In regard to the loss of extraction capacity of M-1 by consumption (sorption) of the sulfate (Figure 4), the three previously excluded soil samples (Figures 2 and 3) exhibit a pattern more consistent with the other soils considered in figure 4. However, they were removed from the figure due to the anomalous behavior observed for $\mathrm{MCPa}$ (Figure 5), as previously observed in the study of the loss of extraction capacity of the acidity in both extractants (Figures 2 and 3).

The same is observed for soil sample 20, with $156.1 \mathrm{mg} \mathrm{dm}^{-3}$ of available P by M-1 and high OM and clay contents, as already mentioned, as well as for samples 16 and 19 (Table 1); the loss of extraction capacity of this extractant follows the general model presented for the other soils (Figure 4).

The loss of extraction capacity of the sulfate in M-1 is noteworthy and is shown in the discontinuous model below (Figure 4). This model was theoretically presented by Novais and Smyth (1999), which indicated that for soils with intermediate PBC values (Figure 1b), the loss of extraction capacity of the extractant, sulfate in this case, occurs up to intermediate values of PBC (Rem-P), but not from there on, for the less buffered soils (with greater Rem-P values).

A similar discontinuity for the CL of $\mathrm{P}$ by M-1 of different soils obtained by Muniz et al. (1987), when plotted by Novais and Smyth (1999), showed a response curve of the "linear-plateau" type $\left(\mathrm{R}^{2}=0.90^{* *}\right)$, similar to that of figure $1 \mathrm{~b}$ and to the curve of loss of extraction capacity of this extractant as a function of the Rem-P (Figure 4). In this new graphic arrangement of the results of Muniz et al. (1987), Novais and Smyth (1999) observed significant dependence of the CL on PBC in soil with Rem-P-30 ${ }^{(4)}<5.33 \mathrm{mg} \mathrm{L}{ }^{-1}$, which corresponds to an estimated clay content of $370 \mathrm{~g} \mathrm{~kg}^{-1}[\mathrm{M}-1 \mathrm{P}=5.31+3.51$ (Rem-P-30)] and a "linear plateau" for lower clay contents $\left(\mathrm{M}-1 \mathrm{P}=24.02 \mathrm{mg} \mathrm{dm}^{-3}\right)$. It is noteworthy that in the study of Muniz et al. (1987) a linear correlation was found between the CL and Rem-P-30 with the fit $\mathrm{CL}=11.2+0.9550\left(\right.$ Rem-P-30), with $\mathrm{r}=0.775^{* *}$ and Rem-P, as a measure of the PBC of the soils.

The information obtained in this study reinforces model "b" of figure 1 and, upon comparing it with the loss of extraction capacity of the M-1 observed (Figure 4), indicates an expressive relationship between the PBC of soils and the CLs of available $\mathrm{P}$, as a consequence of the loss of extraction capacity of the extractant, as discussed by Novais and Smyth (1999).

From all this, it may be perceived that the linear relationship between the $\mathrm{CL}$ of $\mathrm{P}$ in the soil by M-1 and measurements of the PBC such as Rem-P (model "a" in figure 1), although statistically significant, does not in fact portray what happens, i.e., the suitability of model "b" and not of model "a"

(4) Remaining-P obtained after shaking of $30 \mathrm{mg} \mathrm{L}^{-1}$ of $\mathrm{P}$ in $0.01 \mathrm{~mol} \mathrm{~L}^{-1} \mathrm{CaCl}_{2}$ for $1 \mathrm{~h}$ in a soil-solution ratio of 1:10. 


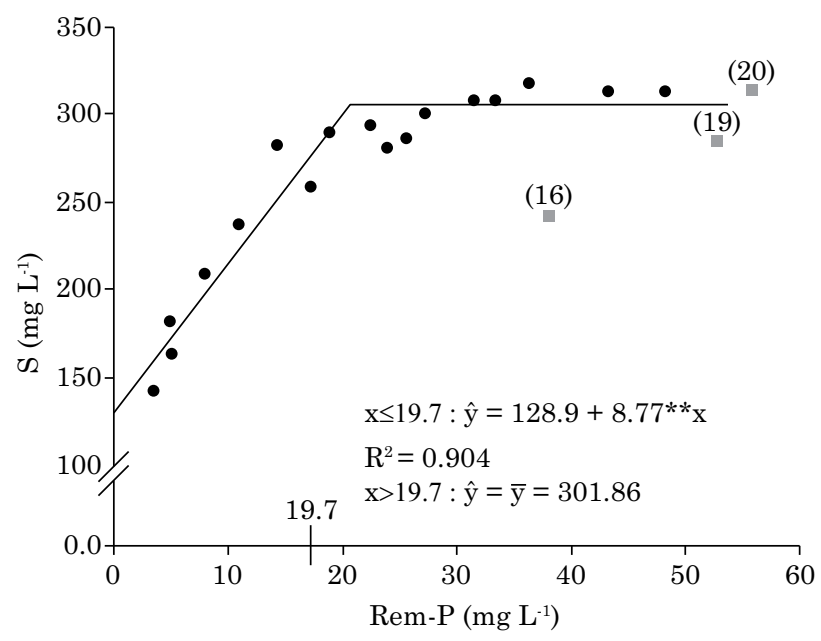

Figure 4. Sulfur concentration in the extract-soil of Mehlich-1, as a variable of remaining $P$ values (Rem-P) of the soils. The three points identified for the soils ( $)$ were excluded from the fit. **: significant at $1 \%$ by the t test. (|) Indicates the Rem-P value for the beginning of the plateau.

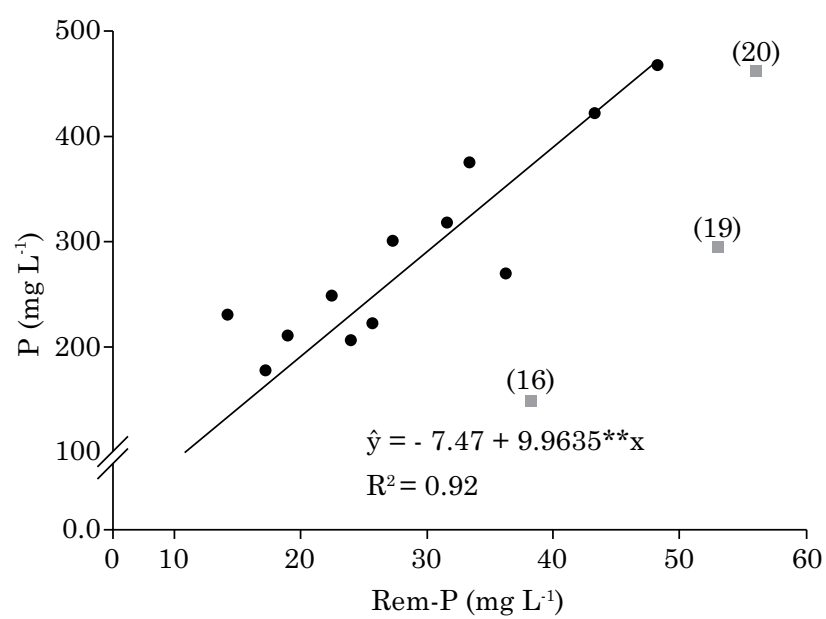

Figure 5. Phosphorus concentration in the extract-soil of Monocalcium Phosphate in acetic acid as a variable of remaining $P$ values (Rem-P) of the soils. The three points identified for the soils ( $\square$ ) were excluded from the fit. **: significant at $1 \%$ by the t test.

of figure 1 , as considered in the studies developed in our conditions over decades (Côrrea et al., 2008, 2011; Simões Neto et al., 2009). With the increase in the OM content in soils, as a consequence of conservationist practices adopted (Rheinheimer and Anghinoni, 2001; Gatiboni et al., 2007) or increase in the remaining $\mathrm{P}$ content over various croppings, or both, the probable "current" model should lean toward model "c" (Figure 1).

Thus, it is possible to speculate that in the " $5^{\text {th }}$ approximation" (Ribeiro et al., 1999), the interpretation table of the $\mathrm{P}$ availability classes in soils that have their values increased in a linear manner with the increase in Rem-P, under the condition for less loss of extraction capacity, is not sufficiently correct, even if the adopted model "a" of figure 1 may be significant, since greater values of $\mathrm{R}^{2}$, as well as better theoretical support with the adoption of model "b", would be obtained. From the results of loss of extraction capacity of M-1 in extraction of soil-available P (Figure 4), the need for changes in the $\mathrm{P}$ availability classes may be indicated, such that for Rem-P values greater than $19.7 \mathrm{mg} \mathrm{L}^{-1}$ (Figure 4), the values of the CL of $\mathrm{P}$ remain constant, regardless of Rem-P values. The clay content corresponding to this value of Rem-P was not able to be estimated, given the non-significant correlation between the two variables $(r=-0.229)$, under the conditions of this study.

Tables from other states [Ribeiro et al. (1999), CQFS-RS/SC (2004), Oliveira (2003), among others] should receive similar treatment. In the recommendation manual for the states of Rio Grande do Sul and Santa Catarina (CQFS-RS/SC, 2004), classification of available $P$ content through M-1 as a variable of the clay content establishes a negative dependence between these two variables, but positive with Rem-P (model "a" of figure 1). However, in the case of flooded soils, only one class is considered, with 41 to $60 \%$ clay, suggesting, for these conditions, the suitability of model "c".

In the loss of extraction capacity of the $\mathrm{MCPa}$ extractant, through adsorption of its phosphate during extraction of available S, its fit with model "a" of figure 1 is noted. This model indicates that with the occurrence of lower values of $\mathrm{PBC}$, associated with the greater values of Rem-P, there is a linear loss of extraction capacity of phosphate during extraction (Figure 5). As a consequence of this behavior, the interpretation table of soil-available $\mathrm{S}$, like that of the " $5^{\text {th }}$ approximation" (Ribeiro et al., 1999), establishes greater CLs of this nutrient with the increase of Rem-P of the soil, consistent with the curve of loss of extraction capacity of the extractant (Figure 5). A mean value of the availability class of this nutrient considered as adequate starts from $4.6 \mathrm{mg} \mathrm{dm}^{-3}$ of $\mathrm{S}$ for soils with Rem-P from 0 to $4 \mathrm{mg} \mathrm{L}^{-1}$ and reaches a maximum value of $22.6 \mathrm{mg} \mathrm{dm}^{-3}$ in those less buffered soils, with Rem-P from 44 to $60 \mathrm{mg} \mathrm{L}^{-1}$ (Alvarez V et al., 1999). Thus, the discontinuous model "b" (Figure 1) that portrays the loss of extraction capacity by consumption of the sulfate during extraction of the M-1 with the increase in $\mathrm{PBC}$, i.e., reduction in Rem-P values, does not apply to $\mathrm{MCPa}$. It is thus plausible to indicate the suitability of the current tables of interpretation of available $\mathrm{S}$ in regard to their theoretical linear model of dependence to the loss of extraction capacity of the extractant, but not of available $\mathrm{P}$ by $\mathrm{M}-1$. 


\section{CONCLUSIONS}

The loss of extraction capacity of the acidity of the extractants Mehlich-1 (M-1) and Monocalcium Phosphate in acetic acid ( $\mathrm{MCPa}$ ) is not very expressive, indicating the small practical effect of this loss of extraction capacity on analysis of $\mathrm{P}$ and $\mathrm{S}$ available in the soil.

The discontinuous loss of extraction capacity of the $\mathrm{SO}_{4}^{2-}$ of M-1 occurs in soils with intermediate values of Phosphate Buffering Capacity in a "linear plateau" model. In contrast, the loss of extraction capacity of the $\mathrm{H}_{2} \mathrm{PO}_{4}^{-}$of $\mathrm{MCPa}$ is linear and continuous throughout the amplitude of variation of remaining $\mathrm{P}$ (Rem-P).

The discontinuous model for loss of extraction capacity of M-1 indicates a likewise discontinuous model for interpretation of soil-available P. In contrast, the linear model observed for $\mathrm{MCPa}$ indicates a likewise linear relationship between the critical levels of $\mathrm{S}$ and the values of Rem-P of the soils, as currently adopted.

\section{REFERENCES}

Alvarez V VH, Dias LE, Ribeiro Jr ES, Souza RB, Fonseca CA. Métodos de análises de enxofre em solos e plantas. Viçosa, MG: Universidade Federal de Viçosa; 2001.

Alvarez V VH, Novais RF, Barros NF, Cantarutti RB, Lopes AS. Interpretação dos resultados das análises de solos. In: Ribeiro AC, Guimarães PTG, Alvarez V VH, editores. Recomendações para o uso de corretivos e fertilizantes em Minas Gerais, $5^{\mathrm{a}}$ aproximação. Viçosa, MG: Comissão de Fertilidade do Solo do Estado de Minas Gerais; 1999. p.25-32.

Alvarez V, VH, Novais RF, Dias LE, Oliveira JA. Determinação e uso do fósforo remanescente. Bol Inf Soc Bras Ci Solo. 2000;25:27-33.

Andrade FV, Mendonça ES, Alvarez V VH, Novais RF. Adição de ácidos orgânicos e húmicos em Latossolos e adsorção de fosfato. R Bras Ci Solo. 2003;27:1003-11.

Bache BW, Williams EG. A phosphate sorption index for soils. J Soil Sci. 1971;22:289-301.

Bahia Filho FC, Braga JM, Resende M, Ribeiro AC. Relação entre adsorção de fósforo e componentes mineralógicos da fração argila de Latossolos do Planalto Central com diferentes características texturais e mineralógicas. R Bras Ci Solo. 1983;7:221-6.

Bedin I, Furtini Neto AE, Resende AV, Faquin V, Tokura AM, Santos JZL. Fertilizantes fosfatados e produção da soja em solos com diferentes capacidades tampão de fosfato. R Bras Ci Solo. 2003;27:639-46.

Bonfim EMS, Freire FJ, Santos MVF, Silva TJA, Freire MBGS. Níveis críticos de fósforo para Brachiaria brizantha e suas relações com características físicas e químicas em solos de Pernambuco. R Bras Ci Solo. 2004;28:281-8.

Comissão de Química e Fertilidade do Solo dos Estados do Rio Grande do Sul e Santa Catarina - CQFSRS/SC. Manual de adubação e de calagem para os Estados do Rio Grande do Sul e Santa Catarina. $10^{\mathrm{a}}$.ed. Porto Alegre: Sociedade Brasileira de Ciência do Solo - Núcleo Regional Sul; 2004.

Corrêa RM, Nascimento CWA, Freire FJ, Souza SKSC, Ferraz GB. Disponibilidade e níveis críticos de fósforo em milho e solos fertilizados com fontes fosfatadas. R Bras Ci Agrár. 2008;3:218-24.

Corrêa RM, Nascimento DC, Rocha DA. Adsorção de fósforo em dez solos do Estado de Pernambuco e suas relações com parâmetros físicos e químicos. Acta Sci Agron. 2011;33:153-9.

Delazari PC. Disponibilidade de fósforo em solos do Estado do Espírito Santo [dissertação]. Viçosa, MG: Universidade Federal de Viçosa; 1979.

Donagemma GK, Ruiz HA, Alvarez V VH, Ker JC, Fontes MPF. Fósforo remanescente em argila e silte retirados de Latossolos após pré-tratamentos na análise textural. $\mathrm{R}$ Bras Ci Solo. 2008;32:1785-91.

Donagemma GK, Ruiz HA, Fontes MPF, Ker JC, Schaefer CEGR. Dispersão de Latossolos em resposta à utilização de pré-tratamentos na análise textural. R Bras Ci Solo. 2003;27:765-72.

Eberhardt DN, Vendrame PRS, Becquer T, Guimarães MF. Influência da granulometria e da mineralogia sobre a retenção do fósforo em Latossolos sob pastagens no Cerrado. R Bras Ci Solo. 2008;32:1009-16.

Empresa Brasileira de Pesquisa Agropecuária - Embrapa. Manual de análises químicas de solos, plantas e fertilizantes. $2^{a}$.ed. rev. Brasília, DF: Embrapa Informação Tecnológica; 2009.

Fernández R I, Novais RF, Nunes FN, Ker JC. Reversibilidade de fósforo não-lábil em solos submetidos à redução microbiana $\mathrm{e}$ química. II - Extrações sucessivas do fósforo pela resina de troca aniônica. R Bras Ci Solo. 2008;32:2319-30.

Fontana A, Pereira MG, Salton JC, Loss A, Cunha TJF. Fósforo remanescente e correlação com as substâncias húmicas em um Latossolo Vermelho sob diferentes sucessões de cultura em plantio direto. R Bras Agroci. 2008;14:161-6.

Freitas IF, Novais RF, Villani EMA, Novais SV. Phosphorus extracted by ion exchange resins and Mehlich-1 from Oxisols (Latosols) treated with different phosphorus rates and sources for varied soil-source contact periods. R Bras Ci Solo. 2013;37:667-77.

Gatiboni LC, Kaminski J, Rheinheimer DS, Flores JPC. Biodisponibilidade de formas de fósforo acumuladas em solo sob sistema plantio direto. R Bras Ci Solo. 2007;31:691-9.

Muniz AS, Novais RF, Freire FM, Neves JCL, Barros NF. Disponibilidade de fósforo e recomendação de adubação avaliadas por meio de extratores químicos e do crescimento de soja em amostras de solo com diferentes valores do fator capacidade. $\mathrm{R}$ Ceres. 1987;34:125-51.

Neves JCL, Novais RF, Barros NF, Muniz AS. Níveis críticos de fósforo em diferentes solos e extratores químicos para o crescimento de mudas de eucalipto. Acta For Bras. 1987;2:64-80.

Nolla A, Anghinoni I. Atividade e especiação química na solução afetadas pela adição de fósforo em Latossolo sob plantio direto em diferentes condições de acidez. $\mathrm{R}$ Bras $\mathrm{Ci}$ Solo. 2006;30:955-63.

Novais RF, Smyth TJ. Fósforo em solo e planta em condições tropicais. Viçosa, MG: Universidade Federal de Viçosa; 1999. 
Novais RF. Phosphorus supplying capacity of previously heavily fertilized soils [tese]. Raleigh: North Carolina State University; 1977.

Oliveira EL. Sugestões de adubação e calagem para culturas de interesse econômico no Estado do Paraná. Londrina: Iapar; 2003. (Circular, 128).

Rampim L, Lana MC, Frandoloso JF. Fósforo e enxofre disponível, alumínio trocável e fósforo remanescente em Latossolo Vermelho submetido ao gesso, cultivado com trigo e soja. Ci Agrár. 2013;34:1623-38.

Rheinheimer DS, Anghinoni I. Distribuição do fósforo inorgânico em sistemas de manejo de solo. Pesq Agropec Bras. 2001;36:151-60.

Ribeiro AC, Guimarães PTG, Alvarez V VH, editores. Recomendações para o uso de corretivos e fertilizantes em Minas Gerais: $5^{\mathrm{a}}$ aproximação. Viçosa, MG: Comissão de Fertilidade do Solo do Estado de Minas Gerais; 1999.

Silva FC, Raij Bvan. Disponibilidade de fósforo em solos avaliada por diferentes extratores. Pesq Agropec Bras. 1999;34:267-88.

Silva IR, Mendonça ES. Matéria orgânica do solo. In: Novais RF, Alvarez V VH, Barros NF, Fontes RLF, Cantarutti RB,
Neves JCL, editores. Fertilidade do solo. Viçosa, MG: Sociedade Brasileira de Ciência do Solo; 2007. p.275-374.

Simões Neto DE, Oliveira AC, Freire FJ, Freire MBGS, Nascimento CWA, Rocha AT. Extração de fósforo em solos cultivados com cana-de-açúcar e suas relações com a capacidade tampão. R Bras Eng Agric Amb. 2009;13:840-8.

Singh B, Gilkes RJ. Posphorus sorption in relation to soil properties for the major soil types of South-western Australia. Aust J Soil Res. 1991;29:603-18.

Souza RB. Níveis críticos de enxofre em solos e em folhas de cultivares de café [tese]. Viçosa, MG: Universidade Federal de Viçosa; 1999.

Viégas RA, Novais RF, Schulthais F. Availability of a soluble phosphorus source applied to soil samples with different acidity levels. R Bras Ci Solo. 2010;34:1125-36.

Vitorino ACT, Ferreira MM, Curi N, Lima JM, Silva MLN, Motta PMF. Mineralogy, chemistry and stability of silt-size aggregates of soils from the Southeast Region of Brazil. Pesq Agropec Bras. 2003;38:133-41.

Yusran FH. The relationship between phosphate adsorption and soil organic carbon from organic matter addition. J Trop Soils. 2010;15:2010-21. 